\title{
Effect of Ethanol on Physical Chemistry Characterization, Microorganism, and Toxicity of Carrageenan Extracted with the Assistant of Enzyme Viscozyme L
}

\author{
Bui Huy Chich", ", Do Van Ninh², Vu Ngoc Boi ${ }^{3}$, Dang Xuan Cuong, * \\ ${ }^{1}$ Department of Science and Technology, Ba Ria-Vung Tau Province, Vung Tau, Vietnam \\ ${ }^{2}$ Pacific Ocean University, MOET, Nha Trang, Vietnam \\ ${ }^{3}$ Faculty of Food Technology, Nha Trang University, Nha Trang, Vietnam \\ ${ }^{4}$ Organic Matterial from Marine Resource, Nhatrang Institute of Technology Application and Research, Vietnam Academy of Science and \\ Technology, Nha Trang, Vietnam
}

\section{Email address:}

chichcntp@gmail.com (B. H. Chich), vaninhcb@yahoo.com (Do V. Ninh), minhboint@yahoo.com (Vu N. Boi), cuong_mails@yahoo.com.vn (D.X.Cuong)

${ }^{*}$ Corresponding author

\section{To cite this article:}

Bui Huy Chich, Do Van Ninh, Vu Ngoc Boi, Dang Xuan Cuong. Effect of Ethanol on Physical Chemistry Characterization, Microorganism, and Toxicity of Carrageenan Extracted with the Assistant of Enzyme Viscozyme L. World Journal of Food Science and Technology. Special Issue: Marine Bio-Polymer: Bio-Activity, Extraction and Application. Vol. 4, No. 1, 2020, pp. 23-30.

doi: $10.11648 /$ j.wjfst.20200401.14

Received: March 17, 2020; Accepted: April 3, 2020; Published: April 29, 2020

\begin{abstract}
Carrageenan is a biopolymer found in red algae with high potential in food, functional food, pharmaceutics, and cosmetics. The study focused on the effect of ethanol on physical chemistry characterization and microorganisms of carrageenan that extracted by the enzyme - assisted method and the purification by using ethanol. The results showed the moisture of carrageenan varied from 10.9 to $9.5 \%$ DW. After the impact of ethanol, the purification and physical (dispersal in water and rheological) characterization of carrageenan was higher than before the impact of ethanol. For example, dispersal in water, the viscosity of the solution, the solution strength ( $1.5 \%$ of carrageenan and $0.2 \%$ of potassium chloride), and carbohydrate content at $20^{\circ} \mathrm{C}$ corresponded to $1.06,1.18,1.07$, and 1.11 times, compared to before the impact of ethanol. The content of ethanol-insolubility impurities, total ash, acid-solubility ash, acid-insolubility ash, total protein, sunphat content $\left(\mathrm{SO}_{4}{ }_{4}^{2-}\right)$, and lipid content was $43 \%, 94.6 \%, 42.9 \%, 44.44 \%, 3.9 \%, 97.2 \%$, and none-detected in comparison to before the impact of ethanol. The content of lead, arsenic, cadmium, and mercury was $0.01,<0.01,0.05$, and $<0.01 \mathrm{ppm}$, respectively. Total aerobic bacterial of carrageenan got the highest value of $2.1 \times 102$ cells/g. E. coli, coliforms, staphylococcus aureus, salmonella, and bacillus cereus did not occur in carrageenan.
\end{abstract}

Keywords: Carrageenan, NMR, Rheology, Mineral, Kappaphycus alvarezii, Cam Ranh

\section{Introduction}

Carrageenans are linear polysaccharides, possess repeating sequences of $\alpha$-D-galactopyranose and $\beta$-D-galactopyranose residues with the 1,3 and 1,4 linkage, named the $A$ residue and $\mathrm{B}$ residues, respectively. The difference in the extraction method and the algae species, types of carrageenans can be obtained different, for example, kappa ( $\kappa)$, iota ( 1 ), and lambda $(\lambda)$ [1-3]. Carrageenans possess good rheological characterizations (forming thermoreversible gels, viscosity) in the salt solutions of small concentration with widely applicating into food [4, 5], functional food [5], pharmaceutics [6,7], and cosmetics [8] in the role of texturing, thickening, suspending, or stabilizing agents $[9$, 10]. Carrageenan is non-toxic, induces thrombosis, anti-cancer, and anti-inflammatory $[11,12]$.

Carrageenan content in red algae is up to $40 \% \mathrm{DW}$ and extracted by using acidic, alkaline, or enzyme depending on the algae species [13]. Almost studies on the carrageenan 
extraction used the chemistry method leading to environmental pollution. The enzyme-assisted extraction method was environmental pollution less than the chemistry method. The carrageenan separation out of the cell membrane is effectively better than the chemistry method. Carrageenan is usually purified by the column causing the difference in the application into the food [13-17].

Thus, the study focused on the effect of ethanol on physical chemistry characterization and microorganisms of carrageenan for finding the solution of carrageenan purification easier.

\section{Material and Methods}

\subsection{Material}

Kappaphycus alverazii (Doty) cultivated commonly in Nha Trang Bay was harvested, and after cleaning by seawater, they were transferred to the laboratory at the condition under $10^{\circ} \mathrm{C}$ for further study.

All chemicals using in the analysis were from Sigma Aldrich. The distilled water and $96 \%$ ethanol was of Vietnam.

\subsection{Sample Preparation}

\subsubsection{Enzyme-assisted Extraction of Carrageenan}

$K$. alvarezii was macerated in the buffer $\left(\mathrm{pH} \mathrm{5.1)}\right.$ at $42^{\circ} \mathrm{C}$ for 60 minutes with $1.45 \%$ of enzyme according to the solution and algae ratio of $20 / 1(\mathrm{v} / \mathrm{w})$. After filtration, the residue was soaked in aqueous at $90^{\circ} \mathrm{C}$ for 80 minutes with the aqueous to residue ratio of $50 / 1(\mathrm{v} / \mathrm{w})$ and collecting the supernatant through the membrane. Carrageenan was continuously precipitated in $80 \%$ ethanol and dried by using the method of freeze-drying for the further studies.

\subsubsection{Purification of Carrageenan by Using Ethanol}

The solution composed of $5 \%$ of carrageenan and $25 \%$ ethanol was kept at $70^{\circ} \mathrm{C}$ for 15 minutes for precipitating dissolved protein and impurities. The supernatant was continuously collected by the centrifugation at $10.000 \mathrm{rpm}$ for 15 minutes, and precipitating in $60 \%$ ethanol for 40 minutes. After precipitation, the residues were filtered, cleaned twice in $96 \%$ ethanol, and dried at $45 \pm 2^{\circ} \mathrm{C}$ by using the freeze drying with the velocity ratio of $2 \mathrm{~m} / \mathrm{s}$.

\subsection{Quantification Methods}

Quantification of moisture was according to the AOAC method [18].

Quantification of solubility in water

The determination of rheology characterization (viscosity and gell strength) was by the machine (Brookfield (American) and CR 500DXS - SunScientific (Japan)), respectively [19].

Quantification of total ash, acid-insoluble ash, and ash soluble in acid was in acordance to the AOACA method (AOAC. 975.12) and Nancy et al. [20].

Quantification of protein content was according to the AOAC method (920.103) based on the nitrogen content with the factor 6.25 [21].
Quantification of sulfate content $\left(\mathrm{SO}_{4}{ }^{2-}\right)$ : One gram of carrageenan was soaked in $50 \mathrm{~mL}$ of $0.2 \mathrm{~N} \mathrm{HCl}$ and boiled for 01 hours. $25 \mathrm{~mL}$ of $\mathrm{H}_{2} \mathrm{O}_{2}$ was then added to the mixture and heated for $05 \mathrm{~h}$. After 05 hours, this solution added to $10 \mathrm{~mL}$ of $10 \% \mathrm{BaCl}_{2}$ and boiled for 02 hours. The residues were filtered through an ashless filter (Whatman No. 42) and removed the residual chloride by using the hot distilled water. The filter paper and precipitate were finally burned at $650^{\circ} \mathrm{C}$ in a furnace and calculating based on equation 5 (JECFA 2007).

Quantification of carbohydrate content was according to the method of Roman (1946) with the standard of glucose, and the absorbance measurement at the wavelength of $490 \mathrm{~nm}$ [22].

The quantification of lipid content was to base using n-hexane [23].

Quantification of the content of $\mathrm{Pb}, \mathrm{As}, \mathrm{Cd}$, and $\mathrm{Hg}$ was by using inductively coupled plasma mass spectrometry [24].

Quantification of total aerobic bacterial

Quantification of Escherichia coli and Coliforms was according to Method 1604 (2002) [25].

Quantification of Staphylococcus aureus was based on the method of AOAC 975.55 [26].

Quantification of Salmonella was according to Denise et al. [27].

Quantification of Bacillus cereus was according to Irena et al. [28].

\subsection{Evaluation of Toxicity}

The toxicity assay of single-dose (safety) was on Swiss white mice consisting of four groups and twelve mice per group (ten male and ten female). Group A, B, C, and D drunk the carrageenan solution of $1.5 \%(\mathrm{w} / \mathrm{v}), 1.0 \%(\mathrm{w} / \mathrm{v}), 0.5 \%$ $(\mathrm{w} / \mathrm{v})$, and physiological saline, respectively. Clinical manifestations and weight of each rat were observed daily for seven consecutive days. All mice were operated on to see the whole organ in the abdominal and thoracic cavity (Table 1). The tissue samples will be taken and sent to histopathology at the Department of Pathology and Forensic Medicine, Hue University of Medicine and Pharmacy as finding any abnormalities. Mice numbers were from 101 to 120,201 to 220,301 to 320 , and 701 to 720 , corresponding to group A, B, $\mathrm{C}$, and control (salt solution), respectively (Table 5). Numbered mice were to the first male and late females.

Table 1. Criteria for evaluating clinical manifestations in safe laboratory rats.

\begin{tabular}{ll}
\hline Symptom & $\begin{array}{l}\text { Evaluation (\%, } \\
\text { appearance date) }\end{array}$ \\
\hline Struggling / stimulating / tiptoeing & No / Yes \\
Sluggishness, poor reflexes with the outside & No / Yes \\
Ruffled feathers & No / Yes \\
Shortness of breath & No / Yes \\
Exudation (watery eyes, runny nose, saliva) & No / Yes \\
Shivering/sweating & No / Yes \\
Distention & No / Yes \\
Vomiting & No / Yes \\
Diarrhea & No / Yes \\
Paralysis or increase/decrease in muscle tone & No / Yes \\
\hline
\end{tabular}




\subsection{Determination of Carrageenan Purification}

The determination of carrageenan purification was by using the NMR spectrum, and carrageenan content before and after purification in $96 \%$ ethanol. 1H-NMR $(500 \mathrm{MHz}$, $\left.\mathrm{CDCl}_{3}\right)$ and $13 \mathrm{C}-\mathrm{NMR}\left(125 \mathrm{MHz}, \mathrm{CDCl}_{3}\right)$ spectrum were determined on the machine Bruker Avance-500 MHz with internal standards of TMS.

\subsection{Data Analysis}

All experiments were in triplication $(n=3)$ and removing unnormal value by the method of Duncan. Statistic analysis was by using the software of MS. Excel 2010.

\section{Results and Discussion}

\subsection{Physical Characterization of Carrageenan}

The results showed ethanol affected the physical chemistry of carrageenan that extracted with the assistance of enzyme Viscozyme $\mathrm{L}$ and the purification by using ethanol. For example, before the impact of ethanol, viscosity of solution $\left(1.5 \%\right.$ of carrageenan) at $75^{\circ} \mathrm{C}$ and the solution strength $(1.5 \%$ of carrageenan and $0.2 \%$ of postassium chlorua) at $20^{\circ} \mathrm{C}$ the content of the moisture corresponded to $80.5 \pm 2.01$ (cPs) and $615 \pm 22.76\left(\mathrm{~g} / \mathrm{cm}^{2}\right)$, respectively. After the impact of ethanol, the viscosity and the strength of the carrageenan solution were $95.3 \pm 2.76$ (cPs) and $657 \pm 15.11 \quad\left(\mathrm{~g} / \mathrm{cm}^{2}\right) \quad$ (Table 2), respectively. Therefore, ethanol caused the improvement of the physical characterization (viscosity and strength of the solution) of carrageenan.

Table 2. Effect of ethanol on physical chemistry characterization of carrageenan.

\begin{tabular}{|c|c|c|c|c|}
\hline \multirow{2}{*}{ Order } & \multirow{2}{*}{ Analysis target } & \multirow{2}{*}{ Unit } & \multicolumn{2}{|l|}{ The results } \\
\hline & & & Before purification & After purification \\
\hline 1 & Moisture & $\% \mathrm{DW}$ & $10.9 \pm 0.23$ & $9.5 \pm 0.27$ \\
\hline 2 & Dispersal in water & $\% \mathrm{DW}$ & $92.5 \pm 1.76$ & $98.2 \pm 2.46$ \\
\hline 3 & Ethanol-insolubility impurities & $\% \mathrm{DW}$ & $1.74 \pm 0.04$ & $0.74 \pm 0.02$ \\
\hline 4 & Viscosity of solution $(1.5 \%$ of carrageenan $)$ at $75^{\circ} \mathrm{C}$ & $\mathrm{cPs}$ & $80.5 \pm 2.01$ & $95.3 \pm 2.76$ \\
\hline 5 & The solution strength ( $1.5 \%$ of carrageenan and $0.2 \%$ of potassium chloride) at $20^{\circ} \mathrm{C}$ & $\mathrm{g} / \mathrm{cm}^{2}$ & $615 \pm 22.76$ & $657 \pm 15.11$ \\
\hline 7 & Total ash content & $\% \mathrm{DW}$ & $20.3 \pm 0.37$ & $19.2 \pm 0.52$ \\
\hline 8 & Acid-solubility ash & $\% \mathrm{DW}$ & $0.7 \pm 0.02$ & $0.3 \pm 0.01$ \\
\hline 9 & Acid-insolubility ash & $\%$ & $0.9 \pm 0.02$ & $0.4 \pm 0.01$ \\
\hline 10 & Total protein content & $\%$ & $5.1 \pm 0.17$ & $0.2 \pm 0$ \\
\hline 11 & Sunphat content $\left(\mathrm{SO}_{4}{ }^{2-}\right)$ & $\%$ & $17.8 \pm 0.52$ & $17.3 \pm 0.4$ \\
\hline 12 & Carbohydrat content & $\%$ & $45.5 \pm 1.64$ & $50.6 \pm 1.42$ \\
\hline 13 & Lipid content & $\%$ & $0.4 \pm 0.02$ & - \\
\hline 14 & Lead content $(\mathrm{Pb})$ & $\mathrm{mg} / \mathrm{kg}$ & 0.023 & 0.01 \\
\hline 15 & Arsenic content (As) & $\mathrm{mg} / \mathrm{kg}$ & 0.038 & $<0.01$ \\
\hline 16 & Cadmium content $(\mathrm{Cd})$ & $\mathrm{mg} / \mathrm{kg}$ & 0.105 & 0.05 \\
\hline 17 & Mercury content $(\mathrm{Hg})$ & $\mathrm{mg} / \mathrm{kg}$ & 0.026 & $<0.01$ \\
\hline
\end{tabular}

\subsection{Microorganisms on Carrageenan}

The microorganisms causing the human diseases did not occur in carrageenan, except for total aerobic bacterial. For example, before and after the impact of ethanol, total aerobic bacterial of carrageenan corresponded to $2.1 \times 10^{3}$ and $10^{\wedge 2}$
Cells/g, respectively. According to the standard of FAO on carrageenan [29], total aerobic bacterial was not excess 5000 CFU/g (Table 3). Therefore, carrageenan in the current study got the standard of FAO.

Table 3. Effect of ethanol on the mircoorganisms of carrageenan.

\begin{tabular}{lllll}
\hline \multirow{2}{*}{ Order } & \multirow{2}{*}{ Microorganism } & \multirow{2}{*}{ Unit } & The results & Before purification \\
\cline { 3 - 4 } & & Cells/g & $2.1 .10^{3}$ & $10^{2}$ \\
2 & Total aerobic bacterial & Cells/g & None detected & None detected \\
3 & Escherichia coli & Cells $/ g$ & None detected & None detected \\
4 & Coliforms & Cells $/ g$ & None detected & None detected \\
5 & Staphylococcus aureus & Cells/25g & None detected & None detected \\
6 & Salmonella & Cells $/ \mathrm{g}$ & None detected & None detected \\
\hline
\end{tabular}

\subsection{Chemical Composition and Characterization}

The results showed ethanol affected the chemical composition and characterization of carrageenan that extracted with the assistance of enzyme Viscozyme $L$ and the purification by using ethanol. For example, before the impact of ethanol, the content of the moisture, the ethanol-insolubility impurities, total ash, acid-solubility ash, acid-insolubility ash, total protein, sulfate $\left(\mathrm{SO}_{4}{ }^{2-}\right)$, carbohydrate, and lipid of carrageenan corresponded to $10.9 \pm 0.23,1.74 \pm 0.04,20.3 \pm 0.37,0.7 \pm 0.02$, $0.9 \pm 0.02,5.1 \pm 0.17,17.8 \pm 0.52,45.5 \pm 1.64,0.4 \pm 0.02 \% \mathrm{DW}$, respectively, and was $1.14,2.35,1.05,2.33,2.25,25.5,1.03$, and 0.9 times, compared to after the impact of ethanol, respectively (Table 2). Lipid did not exist in carrageenan after 
the impact of ethanol. the viscosity of solution $(1.5 \%$ of carrageenan) at $75^{\circ} \mathrm{C}$, and the solution strength $(1.5 \%$ of carrageenan and $0.2 \%$ of potassium chloride) at $20^{\circ} \mathrm{C}$ of carrageenan after the impact of ethanol were higher than before the impact of ethanol. Heavy metal content (lead, arsenic, cadmium, and mercury) of carrageenan after the impact of ethanol was lower than before the impact of ethanol. Cadmium content got the highest value, compared to other metal content for both carrageenan kinds. The maximum value of the content of lead, arsenic, and mercury was $\leq 0.01 \mathrm{ppm}$.

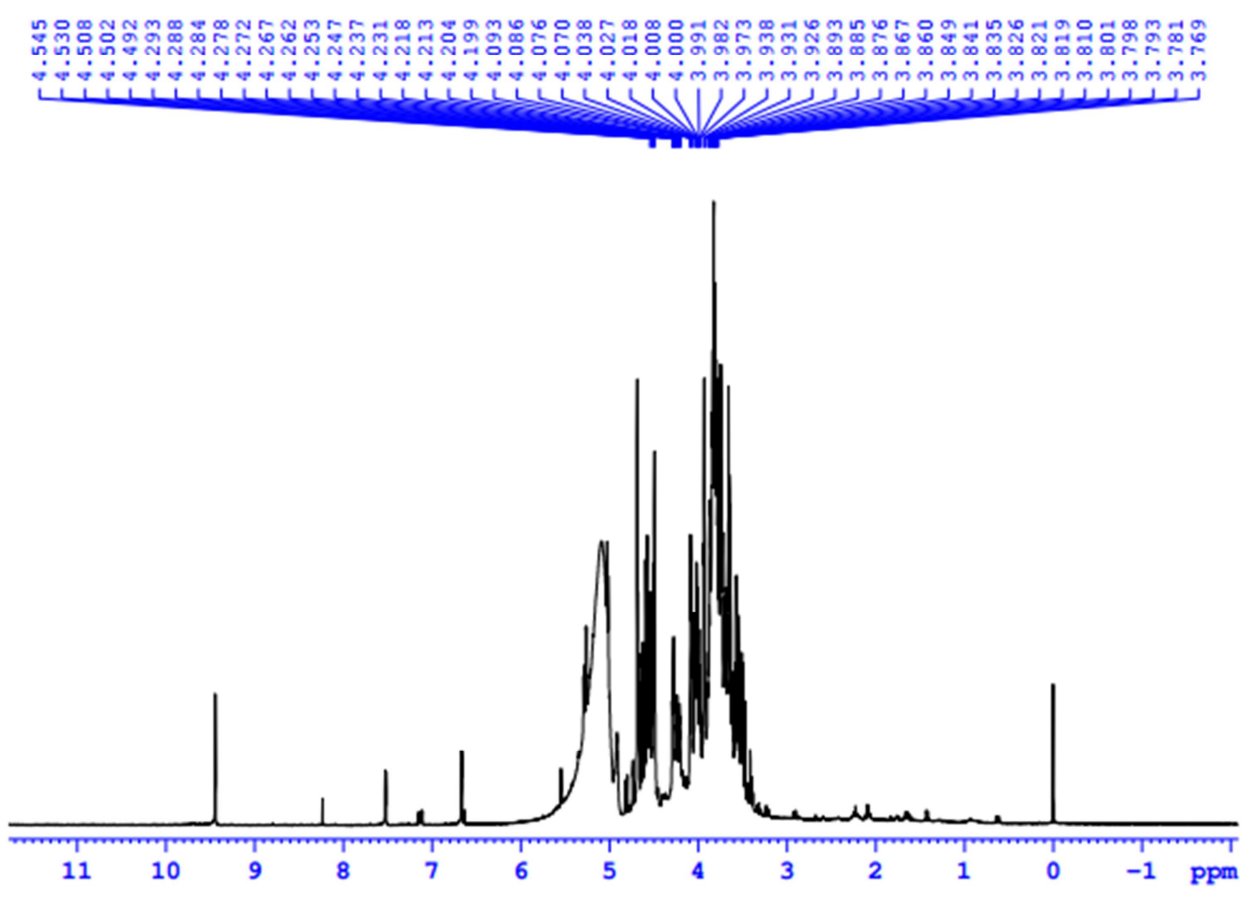

Figure 1. The 1H-NMR spectrum of carrageenan before the impact of ethanol.

$$
\text { MO-D2O-C13CPD }
$$
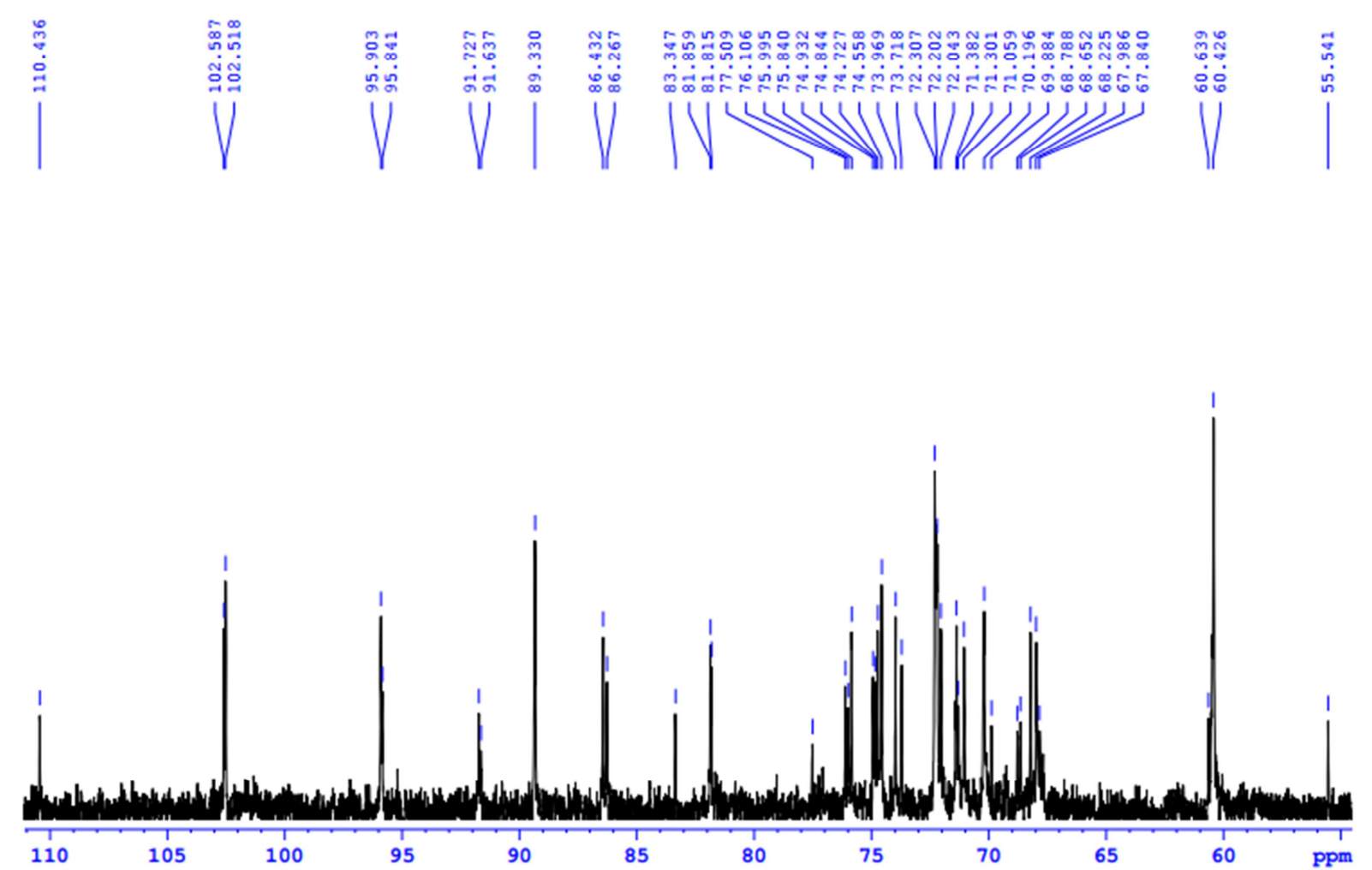

Figure 2. The 13C-NMR spectrum of carrageenan before the impact of ethanol. 
H3-D2O-1H
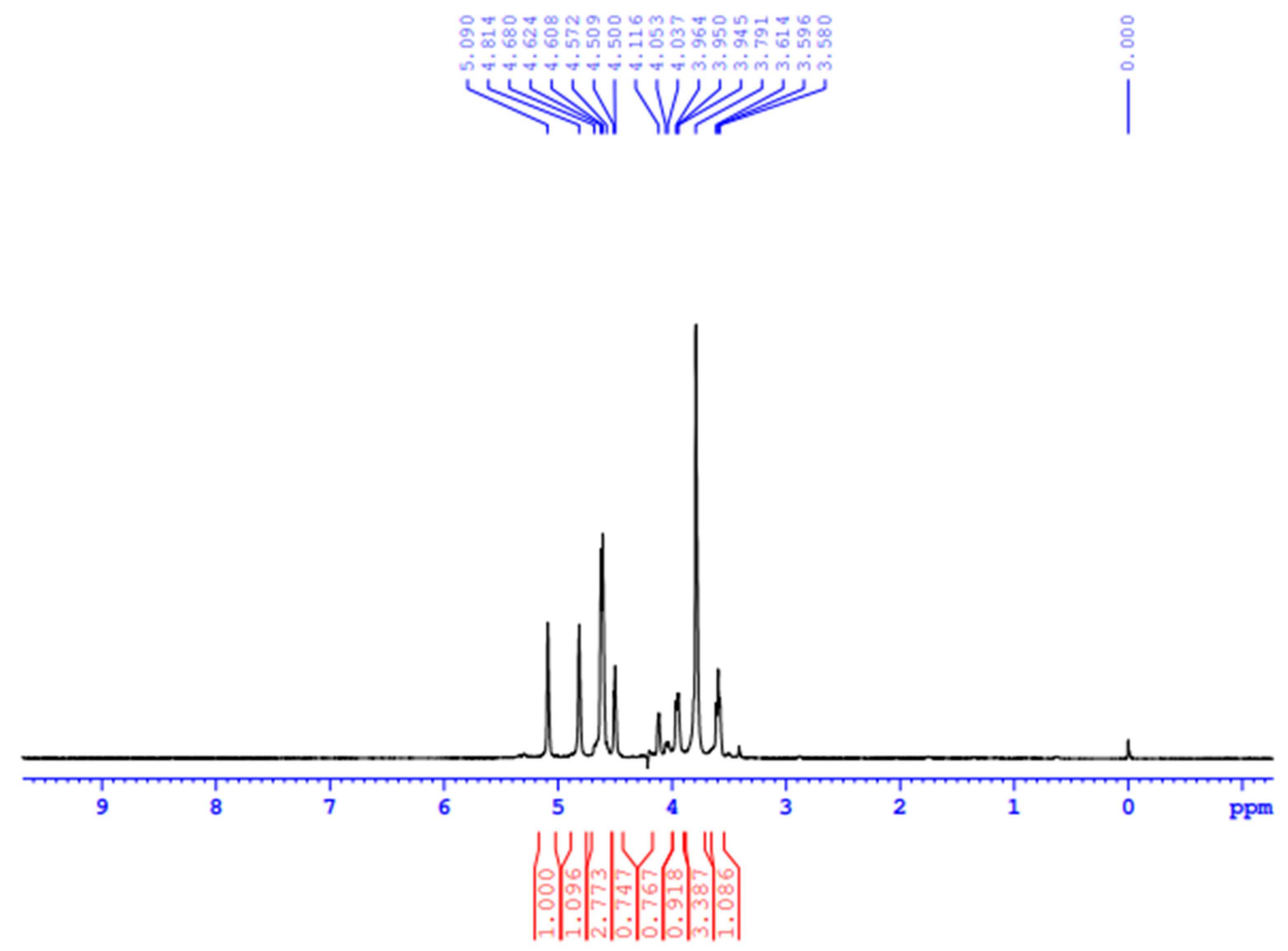

Figure 3. The 1H-NMR spectrum of carrageenan after the impact of ethanol.

H3-D2O-C13CPD

$\mid$
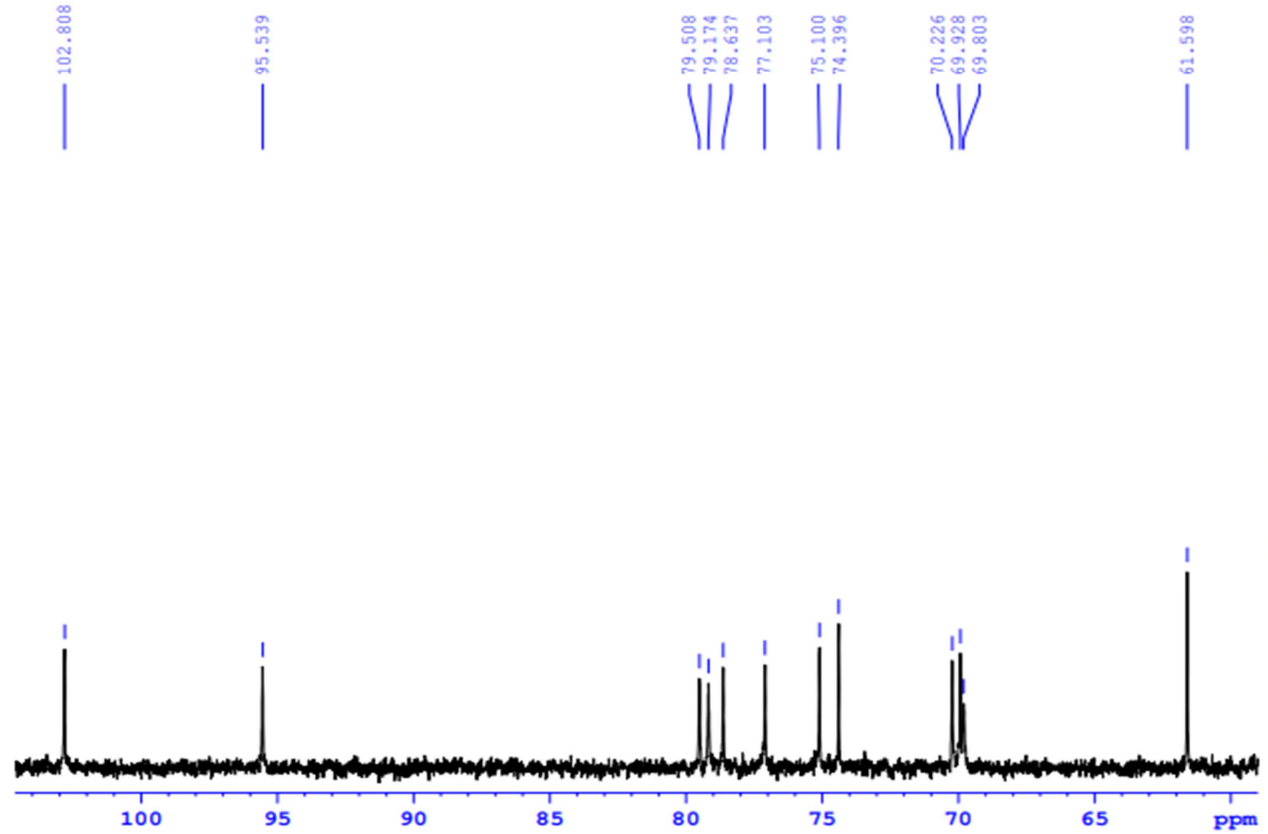

Figure 4. The 13C-NMR spectrum of carrageenan after the impact of ethanol.

The anomeric proton signals $(1 \mathrm{H}$ in the $\beta-\mathrm{D}-\mathrm{Gal}$ residue of carrageenans) exhibited in the range of 4.49 to $4.54 \mathrm{ppm}$ (Figure 1) and 4.5 to $4.57 \mathrm{ppm}$ (Figure 3 ) in the $1 \mathrm{H} \mathrm{NMR}$ spectrum. The signals of $1 \mathrm{H}$ in $\alpha$-D-AnGal residue, $\alpha \mathrm{D}$-AnGal residue, the methyl proton in 6-O-methyl Gal, and methyl hydrogen of carrageenan did not occur in both of $1 \mathrm{H}$ spectrum.
Methylene and methine hydrogens of the carrageenan exhibited in the range of 3.76 to 4.5 (Figure 1) and 3.5 to 4.81 ppm (Figure 3). The signal range at $102.5 \& 91.72,91.7$, and 95.8 \& 95.9 ppm exhibited anomeric carbon resonance pairs attributed to the pyruvated $\alpha-$, methylated $\alpha$ - and 1 carrageenans, respectively (Figure 2). The anomeric carbon 
resonance pairs belonging to pyruvate and 1 carrageenans occurred in the signal range at 102, 95.5 (Figure 4). $60.4 \&$ 60.6 (Figure 2), and 61.3 (Figure 4) of the carbon resonance were belonging to the methylated C-6 of 3-linked galactose. 13C NMR resonances at $101.0 \mathrm{ppm}$ indicated the acetal group of the pyruvate unit. C-4 and C-5 of the 3-linked pyruvate galactose unit exhibited in the signals at 67.8 and $67.9 \mathrm{ppm}$. The signal at a range of 6 to $7 \mathrm{ppm}$ was the characterization for protein impurities that existed in carrageenan. This signal was consistent with the results of the analysis of physical and chemical indicators of pre-purified carrageenan samples and showing that the protein existed in the initial carrageenan sample. The peak at $6 \div 7 \mathrm{ppm}$ did not occur in figure 4 . Some peaks at the range of $4 \mathrm{ppm}$ in figure 2 were more than figure 4 , was the characterization of protein and lipid. The information was suitable for the analysis results of physical chemistry of carrageenan before and after the purification by ethanol. Thus, ethanol was useful to the purification of carrageenan.

\subsection{Toxicity of Carrageenan After Purification}

\subsubsection{Clinical Manifestations in Mice}

After seven days of testing, mice were given carrageenan at different concentrations without any clinical symptoms compared to the control samples (Table 4).

Table 4. Clinical manifestations of mice drinking Carrageenan and control.

\begin{tabular}{|c|c|c|c|c|}
\hline Symptoms & Group A & Group B & Group C & Control group \\
\hline Struggling / stimulating / tiptoeing & None & None & None & None \\
\hline Sluggishness, poor reflexes with the outside & None & None & None & None \\
\hline Ruffled feathers & None & None & None & None \\
\hline Exudates (watery eyes, runny nose, saliva) & None & None & None & None \\
\hline Shivering/sweating & None & None & None & None \\
\hline Distention & None & None & None & None \\
\hline Diarrhea & None & None & None & None \\
\hline Paralysis or increase/decrease in muscle tone & None & None & None & None \\
\hline
\end{tabular}

Note: None: none-detection.

\subsubsection{Mice Weight}

Table 5. Mice weight drinking Carrageenan and control after seven days.

\begin{tabular}{|c|c|c|c|c|c|c|c|c|}
\hline \multirow{2}{*}{$\begin{array}{l}\text { Mice } \\
\text { code }\end{array}$} & \multicolumn{8}{|c|}{ Weight (g) per day } \\
\hline & D0 & D1 & D2 & D3 & D4 & D5 & D6 & D7 \\
\hline 101 & 20.5 & 21.6 & 22.8 & 24.3 & 25.4 & 26.7 & 28.3 & 30.2 \\
\hline 102 & 20.2 & 21.5 & 22.7 & 24.2 & 25.8 & 26.8 & 28.3 & 30.2 \\
\hline 103 & 19.5 & 20.5 & 21.7 & 23.2 & 24.2 & 25.5 & 27.0 & 28.9 \\
\hline 104 & 20.0 & 21.5 & 22.6 & 24.1 & 25.5 & 26.7 & 28.2 & 29.8 \\
\hline 105 & 20.7 & 21.9 & 23.3 & 24.7 & 26.1 & 27.3 & 28.4 & 30.1 \\
\hline 106 & 20.3 & 21.3 & 22.4 & 23.8 & 25.2 & 26.4 & 27.7 & 29.8 \\
\hline 107 & 18.4 & 19.5 & 20.6 & 22.0 & 23.4 & 24.4 & 25.7 & 27.3 \\
\hline 108 & 18.1 & 19.5 & 20.7 & 22.1 & 23.3 & 24.6 & 25.9 & 27.5 \\
\hline 109 & 18.6 & 19.9 & 21.4 & 22.9 & 24.1 & 25.4 & 26.4 & 29.5 \\
\hline 110 & 20.0 & 21.1 & 22.6 & 23.9 & 25.1 & 26.1 & 27.8 & 30.2 \\
\hline 111 & 18.3 & 19.4 & 20.9 & 22.2 & 23.6 & 25.0 & 26.7 & 29.1 \\
\hline 112 & 18.7 & 19.9 & 21.1 & 22.4 & 23.8 & 25.2 & 26.9 & 29.0 \\
\hline 113 & 18.6 & 20.0 & 21.2 & 22.5 & 24.2 & 25.6 & 27.4 & 28.3 \\
\hline 114 & 19.0 & 20.1 & 21.7 & 23.4 & 25.1 & 26.5 & 27.9 & 30.0 \\
\hline 115 & 19.6 & 20.9 & 22.5 & 24.0 & 25.5 & 27.1 & 28.5 & 31.0 \\
\hline 116 & 19.9 & 21.3 & 23.1 & 24.6 & 26.0 & 27.4 & 28.8 & 30.5 \\
\hline 117 & 18.8 & 19.8 & 21.4 & 23.0 & 24.4 & 25.7 & 27.1 & 28.7 \\
\hline 118 & 18.4 & 19.5 & 20.7 & 22.3 & 23.8 & 25.1 & 26.7 & 29.2 \\
\hline 119 & 20.0 & 21.3 & 22.5 & 24.1 & 25.6 & 27.2 & 28.8 & 30.2 \\
\hline 120 & 19.3 & 20.7 & 22.0 & 23.6 & 25.1 & 26.7 & 28.3 & 30.2 \\
\hline 201 & 18.3 & 19.6 & 21.3 & 22.9 & 24.4 & 26.0 & 27.6 & 28.3 \\
\hline 202 & 20.5 & 21.9 & 23.2 & 24.8 & 26.2 & 27.5 & 29.0 & 32.2 \\
\hline 203 & 18.0 & 19.1 & 20.4 & 21.9 & 23.3 & 24.6 & 26.1 & 28.9 \\
\hline 204 & 18.3 & 20.1 & 21.1 & 22.6 & 24.0 & 25.2 & 26.7 & 29.0 \\
\hline 205 & 18.2 & 19.7 & 20.9 & 22.4 & 24.0 & 25.2 & 26.7 & 28.8 \\
\hline 206 & 18.0 & 19.6 & 21.0 & 22.5 & 24.1 & 25.3 & 26.9 & 27.9 \\
\hline 207 & 19.4 & 20.8 & 21.8 & 23.1 & 24.7 & 26.0 & 27.2 & 29.1 \\
\hline 208 & 19.5 & 21.0 & 22.4 & 23.7 & 25.4 & 26.7 & 27.9 & 29.7 \\
\hline 209 & 19.7 & 21.0 & 22.2 & 23.5 & 24.9 & 26.3 & 27.9 & 29.2 \\
\hline 210 & 18.1 & 19.7 & 20.9 & 22.2 & 23.6 & 25.0 & 26.6 & 28.3 \\
\hline
\end{tabular}

\begin{tabular}{|c|c|c|c|c|c|c|c|c|}
\hline \multirow{2}{*}{$\begin{array}{l}\text { Mice } \\
\text { code }\end{array}$} & \multicolumn{8}{|c|}{ Weight (g) per day } \\
\hline & D0 & D1 & D2 & D3 & D4 & D5 & D6 & D7 \\
\hline 211 & 20.5 & 21.9 & 23.1 & 24.6 & 26.2 & 27.5 & 29.1 & 31.0 \\
\hline 212 & 20.2 & 21.5 & 22.7 & 24.2 & 25.8 & 27.1 & 28.6 & 30.5 \\
\hline 213 & 19.5 & 20.9 & 22.1 & 23.6 & 25.2 & 26.5 & 28.0 & 29.9 \\
\hline 214 & 20.0 & 21.5 & 22.6 & 24.1 & 25.5 & 26.7 & 28.2 & 29.8 \\
\hline 215 & 20.7 & 21.9 & 23.0 & 24.4 & 25.8 & 27.0 & 28.6 & 30.1 \\
\hline 216 & 20.3 & 21.7 & 22.8 & 24.2 & 25.6 & 26.8 & 28.1 & 29.8 \\
\hline 217 & 18.4 & 20.0 & 21.1 & 22.5 & 23.9 & 25.1 & 26.4 & 27.3 \\
\hline 218 & 18.1 & 19.5 & 20.7 & 22.1 & 23.3 & 24.6 & 25.9 & 27.5 \\
\hline 219 & 18.6 & 19.9 & 21.4 & 22.9 & 24.1 & 25.4 & 27.0 & 29.5 \\
\hline 220 & 20.0 & 21.1 & 22.6 & 23.9 & 25.1 & 26.5 & 28.2 & 30.2 \\
\hline 301 & 18.3 & 19.4 & 21.2 & 22.2 & 23.6 & 24.6 & 26.3 & 29.1 \\
\hline 302 & 18.7 & 19.9 & 21.5 & 22.5 & 23.9 & 25.3 & 27.0 & 29.0 \\
\hline 303 & 18.6 & 20.0 & 21.9 & 22.9 & 24.6 & 26.0 & 27.6 & 28.3 \\
\hline 304 & 19.0 & 20.3 & 21.9 & 22.1 & 23.8 & 25.2 & 26.6 & 30.0 \\
\hline 305 & 19.6 & 20.6 & 22.2 & 23.2 & 24.7 & 25.8 & 27.2 & 31.0 \\
\hline 306 & 19.9 & 21.3 & 22.9 & 23.9 & 25.3 & 26.7 & 28.1 & 30.5 \\
\hline 307 & 18.8 & 20.5 & 21.9 & 22.3 & 23.7 & 24.9 & 26.3 & 28.7 \\
\hline 308 & 18.4 & 19.5 & 20.7 & 21.7 & 23.2 & 24.5 & 26.1 & 29.2 \\
\hline 309 & 20.0 & 21.3 & 22.5 & 23.5 & 25.0 & 26.6 & 28.2 & 30.2 \\
\hline 310 & 19.3 & 20.7 & 22.0 & 23.0 & 24.5 & 25.7 & 27.3 & 30.2 \\
\hline 311 & 18.3 & 19.6 & 20.9 & 22.5 & 24.0 & 25.6 & 27.2 & 28.3 \\
\hline 312 & 20.5 & 21.9 & 23.2 & 24.8 & 26.2 & 27.5 & 29.0 & 32.2 \\
\hline 313 & 18.0 & 19.5 & 20.8 & 22.3 & 23.7 & 25.0 & 26.5 & 28.9 \\
\hline 314 & 18.3 & 19.9 & 21.1 & 22.6 & 24.0 & 25.2 & 26.7 & 29.0 \\
\hline 315 & 18.2 & 19.4 & 20.6 & 22.1 & 23.7 & 24.9 & 26.4 & 28.8 \\
\hline 316 & 18.0 & 19.3 & 20.7 & 22.2 & 23.8 & 25.0 & 26.6 & 27.9 \\
\hline 317 & 19.4 & 20.8 & 22.2 & 23.5 & 25.1 & 26.4 & 27.6 & 29.1 \\
\hline 318 & 19.5 & 21.0 & 22.4 & 23.7 & 25.1 & 26.4 & 27.6 & 29.7 \\
\hline 319 & 19.7 & 21.5 & 22.7 & 24.0 & 25.4 & 26.8 & 28.4 & 29.2 \\
\hline 320 & 18.1 & 19.7 & 20.9 & 22.2 & 23.6 & 25.0 & 26.6 & 28.3 \\
\hline 701 & 19.0 & 20.3 & 21.6 & 22.8 & 24.0 & 25.6 & 27.6 & 30.1 \\
\hline 702 & 19.0 & 20.2 & 21.5 & 22.7 & 23.9 & 25.5 & 27.5 & 28.7 \\
\hline 703 & 18.0 & 19.1 & 20.4 & 21.6 & 22.8 & 24.4 & 26.4 & 28.3 \\
\hline 704 & 18.1 & 19.4 & 20.7 & 21.9 & 23.1 & 24.7 & 26.7 & 27.8 \\
\hline 705 & 18.6 & 20.0 & 21.3 & 22.5 & 23.7 & 25.3 & 27.3 & 29.8 \\
\hline
\end{tabular}




\begin{tabular}{lllllllll}
\hline \multirow{2}{*}{$\begin{array}{l}\text { Mice } \\
\text { code }\end{array}$} & \multicolumn{9}{l}{ Weight (g) per day } & D0 & D1 & D2 & D3 & D4 & D5 & D6 & D7 \\
\hline 706 & 18.9 & 20.4 & 21.7 & 22.9 & 24.1 & 25.7 & 27.7 & 29.5 \\
707 & 18.6 & 20.0 & 21.3 & 22.5 & 23.7 & 25.3 & 27.3 & 29.0 \\
708 & 18.4 & 20.0 & 21.3 & 22.5 & 23.7 & 25.3 & 27.3 & 28.8 \\
709 & 19.4 & 20.7 & 22.0 & 23.2 & 24.4 & 26.0 & 28.0 & 29.3 \\
710 & 18.7 & 20.2 & 21.5 & 22.7 & 23.9 & 25.5 & 27.5 & 28.7 \\
711 & 18.9 & 20.3 & 21.6 & 23.0 & 24.4 & 25.5 & 26.6 & 28.1 \\
712 & 18.7 & 19.9 & 21.2 & 22.3 & 23.7 & 24.8 & 25.9 & 27.9 \\
713 & 18.7 & 20.2 & 21.5 & 22.7 & 24.1 & 25.2 & 26.3 & 28.0 \\
714 & 19.6 & 20.9 & 22.2 & 23.4 & 24.6 & 26.2 & 28.2 & 31.0 \\
715 & 19.7 & 21.1 & 22.4 & 23.6 & 24.8 & 26.4 & 28.4 & 30.0 \\
716 & 20.5 & 21.8 & 23.1 & 24.3 & 25.5 & 27.1 & 29.1 & 33.0 \\
717 & 19.0 & 20.2 & 21.5 & 22.7 & 23.9 & 25.5 & 27.5 & 28.9 \\
718 & 19.2 & 20.7 & 22.0 & 23.2 & 24.4 & 26.0 & 28.0 & 29.4 \\
719 & 19.4 & 20.7 & 22.0 & 23.2 & 24.4 & 26.0 & 28.0 & 29.3 \\
720 & 18.4 & 20.0 & 21.3 & 22.5 & 23.7 & 25.3 & 27.3 & 28.6 \\
\hline
\end{tabular}

Note: $\mathrm{D}_{\mathrm{i}}$ : day i. i was from 0 to 7.

Carrageenan oral mice: mice weight increased from 9.7 to $10.5 \mathrm{~g} /$ rat (increased by $50-55 \%$, respectively), compared to the initial weight. The increase in mice weight was not different insignificance $(p>0.05)$ between other groups. Therefore, purified carrageenan by ethanol was non-toxicity.

\subsubsection{Pathology}

Abnormalities in the organs belong to the abdominal and thoracic of the rat were not found after surgery (Figure 5). The lymph nodes, tumors, bleeding signs, abnormal fluid retention in the abdominal and chest cavities did not appear.

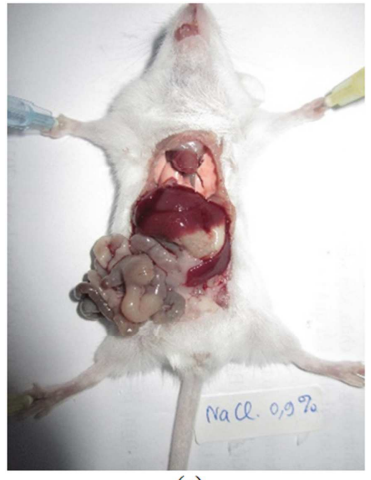

(a)

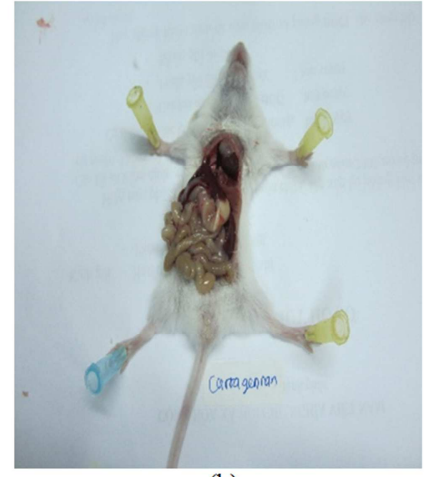

(b)
Figure 5. Mice drunk physiological saline (a) and carrageenan (b).

With the results of clinical observation, weight monitoring, and anatomy, it said that carrageenan was non-toxic and safe.

\section{Conclusion}

After the impact of ethanol, the purification and physical (dispersal in water and rheological) characterization of carrageenan was higher than before the impact of ethanol. For example, dispersal in water, the viscosity of the solution, the solution strength $(1.5 \%$ of carrageenan and $0.2 \%$ of potassium chloride), and carbohydrate content at $20^{\circ} \mathrm{C}$ corresponded to $1.06,1.18,1.07$, and 1.11 times, compared to before the impact of ethanol. The content of ethanol-insolubility impurities, total ash, acid-solubility ash, acid-insolubility ash, total protein, sunphat content $\left(\mathrm{SO}_{4}{ }^{2-}\right)$, and lipid content was
$43 \%, 94.6 \%, 42.9 \%, 44.44 \%, 3.9 \%, 97.2 \%$, and none-detected in comparison to before the impact of ethanol. The content of lead, arsenic, cadmium, and mercury was $0.01,<0.01,0.05$, and $<0.01 \mathrm{ppm}$, respectively. Total aerobic bacterial of carrageenan got the highest value of $2.1 \times 10^{2}$ cells $/ g$. E. coli, coliforms, staphylococcus aureus, salmonella, and bacillus cereus did not occur in carrageenan. Purified carrageenan by using ethanol was non-toxic.

\section{Acknowledgements}

The authors thank Vietnam Ministry of Agriculture and Rural Development, Department of Science and Technology (Ba Ria-Vung Tau province), Faculty of Food Technology (Nha Trang University), Pacific Oceanography University, and Nha Trang Insitute of Technology Application and Research for helping.

\section{References}

[1] Álvarez R., Araya, H., Navarro-Lisboa, R. and Lopez, d. D. C. (2016). Evaluation of polyphenol content and antioxidant capacity of fruits and vegetables using a modifi ed enzymatic extraction. Food Technol Biotechnol, 54 (4): 462-467.

[2] Necas J. and Bartosikova, L. (2013). Carrageenan: a review. Vet Med-Czech, 58 (4): 187-205.

[3] Sankalia M., Mashru, R., Sankalia, J. and Sutariya, V. (2006). Stability improvement of alpha-amylase entrapped in kappa-carrageenan beads: physicochemical characterization and optimization using composite index. Int J Pharm, 312 (1-2) $1-14$.

[4] Sarah H., Mariel, B., Ross, C., Kevin, P. and Angie, T. (2016). Chapter 10 - The use of carrageenan in food. Carrageenans. Leonel, P, Nova Science Publishers, Inc.

[5] Błażej B., Grażyna, G. and Alexander, S. (2018). Carrageenan as a functional additive in the production of cheese and cheese-like products. Acta Sci Pol Technol Aliment, 17 (2): 107-116.

[6] Li L., Ni, R., Shao, Y. and Mao, S. (2014). Carrageenan and its applications in drug delivery. Carbohydr Polym, 103 1-11.

[7] Abida K. K., et al. (2017). Carrageenan based bionanocomposites as drug delivery tool with special emphasis on the influence of ferromagnetic nanoparticles. Oxid Med Cell Longev 1-13.

[8] Abdul B. A. A., Mohaddeseh Adel, Pegah, K. and Mahvash, P. (2014). Chapter Ten - Pharmaceutical, Cosmeceutical, and Traditional Applications of Marine Carbohydrates. Adv Food Nutr Res, 73 197-220.

[9] Roos G., Cheshire, A., Nayar, S., Clarke, S. M. and Zhang, W., Harnessing marine macroalgae for industrial purposes in an australian context: emerging research and opportunities: Emerging research and opportunities, Hershey PA, USA: IGI Global, 2018, pp. 34.

[10] Nussinovitch A., Hydrocolloid Applications, Doyle Graphics, Tullamore, Ireland: Springer Science+Business Media Dordrecht, 1997, pp. 40-58. 
[11] Zhiwei L., et al. (2019). Anti-Cancer Activity of Porphyran and Carrageenan from Red Seaweeds. Molecules, 24 (23): 4286-4299.

[12] Ning M., et al. (2015). Preventive effect of aspirin eugenol ester on thrombosis in $\kappa$-carrageenan-induced rat tail thrombosis model. PLoS One, 10 (7): e0133125.

[13] Vanessa W., Sabrina, M. D. C., Paulo, J. O., Leila, H. and Pedro, L. M. B. (2012). Optimization of the extraction of carrageenan from Kappaphycus alvarezii using response surface methodology. Ciênc Tecnol Aliment Campinas, 32 (4): 812-818.

[14] Sitti N., Syarief, R. S., Peranginangin, R., Nurtama, B. and Jaswir, I. (2017). Production of refined carrageenan from Kappaphycus alvarezii on pilot plant scale: optimization of water extraction using response surface methodology. Int Food Res J, 24 (Suppl): S522-S528.

[15] Nanna R.-K., Marcel, T. A. and Anne, S. M. (2015). Seaweed hydrocolloid production: An update on enzyme assisted extraction and modification technologies. Mar Drugs, 13 (6): 3340-3359.

[16] Blanco-Pascual N., Aleman, A., G ' omez-Guill' en, M. and Montero ', M. (2014). Enzyme-assisted extraction of k/i-hybrid carrageenan from Mastocarpus stellatus for obtaining bioactive ingredients and their application for edible active film development. Food Funct, 5 319-329.

[17] Soma C. (2017). Carrageenan for encapsulation and immobilization of flavor, fragrance, probiotics, and enzymes: A review. J Carbohydr Chem, 36 (1): 1-19.

[18] William H. and George, W. L., Official methods of analysis of AOAC International, 18th, Arlington, VA, USA: Gaithersburg, Md.: AOAC International, 2005.

[19] Awang B., Anisuzzaman, S. and Wan, D. O. (2014). Effect of process conditions on the gel viscosity and gel strength of semi-refined carrageenan (SRC) produced from seaweed (Kappaphycus alvarezii). JKSUES, 26 (1): 3-9.

[20] Nancy J. T., Lawrence, N. and Andy, C. (2012). Quantification of ash soluble in acid (Determination of Ash in Animal Feed: AOAC Official Method 942.05). Journal of AOAC International, 95 (5): 1392-1397.

[21] Latimer G., Official Methods of Analysis of AOAC International, Gaithersburg, MD, USA: AOAC International, 2016.

[22] Roman D. (1946). Qualitative test for carbohydrate material. Ind Eng Chem Anal Ed, 18 (8): 499-499.

[23] AOAC, Fat in foods. Chloroform-methanol extraction method: Method 983.23, 19th, Gaithersburg, MD, USA: AOAC International, 2012.

[24] Julshamn K., et al. (2013). Determination of arsenic, cadmium, mercury, and lead in foods by pressure digestion and inductively coupled plasma/ mass spectrometry: first action 2013.06. J AOAC Int, 96 (5): 1101-1102.

[25] Method 1604 (2002). Total Coliforms and Escherichia coli in water by membrane filtration using a simultaneous detection technique (mi medium). EPA-821-R-02-024. (4303T) 1200 Pennsylvania Avenue, NW Washington, DC 20460., U.S. Environmental Protection Agency Office of Water.

[26] Silbernagel K., Jechorek, R., Carver, C., Horter, B. and Lindberg, K. (2003). 3M Petrifilm staph express count plate method for the enumeration of Staphylococcus aureus in selected types of processed and prepared foods: collaborative study. J AOAC Int, 86 (5): 954-962.

[27] Denise H., Angela, E. D. and Louise, H. (2003). Salmonella in Foods: new enrichment procedure for tecra salmonella visual immunoassay using a single RV (R10) only, TT only, or Dual RV (R10) and TT selective enrichment broths (AOAC Official method 998.09): Collaborative study. J AOAC Int, 86 (4): 775-790.

[28] Irena N., Kateřina, S., Petr, R., Barbora, U. and Eva, Š. (2011). Methods for detection of Bacillus sp., B. cereus, and B. licheniformis in raw milk. Czech J Food Sci, 29 (S55-S60).

[29] FAO/WHO, Compendium of food additive specifications, Rome, Italy: FAO/WHO, 2014, pp. 7-16. 